\title{
Analysis of Track Gauge Widening in Curves with Small Radius
}

\author{
Zdenka Popović $^{1, a^{*}}$, Luka Lazerević ${ }^{2, b}$, Nikolay Vatin ${ }^{3, c}$ \\ ${ }^{1,2}$ Faculty of Civil Engineering, University of Belgrade, 11000 Belgrade, Serbia \\ ${ }^{3}$ St.Petersburg State Polytechnical University, 195251, Saint-Petersburg, Russia \\ azdenka@grf.bg.ac.rs, ${ }^{\mathrm{l}}$ llazarevic@grf.bg.ac.rs, ${ }^{\mathrm{c}}$ vatin@mail.ru
}

Keywords: Railway, track, curve, track gauge, locomotive, bogie.

\begin{abstract}
In this paper it was performed curve negotiation analysis of three axle bogie of locomotive type JŽ 461. This locomotive has large distance between first and middle i.e. middle and last axle, which leads to increased lateral forces during curve negotiation. Final result might be widening of track gauge in curves with small radius. This paper points that Infrastructure Manager must take into account vehicle performances and type of track when defines track gauge in curves.
\end{abstract}

\section{Introduction}

When vehicles travel through curves, forces that increase the wear and tear of the track are generated, and thus the potential for derailment. These forces need to be minimised by designing the curve using maximum practical radius, together with one or more of the following additional measures if necessary: superelevation of the outer rail, check rails fitted to the inner rail, and/or gauge widening.

In order to improve curve traversing of the vehicle, small radius curves may require gauge widening. Due to lateral forces on the wheels in curves with small radius, the track gauge gets widened and the rails get inclined outward. To prevent the tendency of outward inclination of the rails, the track gauge in curves with small radius is designed with appropriate widening. The amount of gauge widening depends on the curve radius, type of track and rigid wheel base of the vehicles. [1-7]

In this paper it was performed curve negotiation analysis of three axle bogie of locomotive type JŽ 461. This locomotive has two bogies, both with three axles. Distance between bolsters of bogies is $10.3 \mathrm{~m}$. Bogies are connected with elastic diagonal links for the purpose of better curve negotiation. Technical documentation of this locomotive states that minimal track radius is $90 \mathrm{~m}$. Due to large distance between first and middle i.e. middle and last axle, it occurs increased lateral forces during curve negotiation, as it is shown in consideration below.

\section{Curve negotiation analysis}

It was investigated necessary geometrical conditions for curve negotiation of three axle bogie of locomotive type $\mathrm{JZ} \breve{\mathrm{C}} 461$ through curves with radius from $\mathrm{R}=300 \mathrm{~m}$ to $\mathrm{R}=500 \mathrm{~m}$. Among other performances of this locomotive, the most important for curve negotiation analysis are bogie axle distance $2700 \mathrm{~mm}$, mass of locomotive $120 \mathrm{t} \pm 2 \%$, and axle load $200 \mathrm{kN} \pm 3 \%$.

During curve negotiation, tree axles remain parallel, or nearly parallel. Due to rigid guiding in rolling direction, it occurs additional friction force between wheel and rail. Additional friction is the consequence of: longitudinal creep of wheels on the same axle due to path length difference, lateral slip of wheels on inclined track level, increased slip between wheel flange and rail due to forced guidance of wheel set, and centrifugal force. Force which occurs during curve negotiation is influenced by: condition of wheels and rail head, track curve radius, length of rigid wheelbase, track width and other parameters (impurities of contact surfaces, climate conditions and similar) [8,9].

Fig. 1 shows the preferred inclined loose position of three axle bogie in curve as well as lateral forces and longitudinal friction forces, which affect the vehicle during curve traversing. 
Unfortunately, the three axle bogie with long rigid wheelbase (distance between first and last bogie axle of locomotive JŽ 461 is $2 \times 2.7=5.4 \mathrm{~m}$ ) is usually in the chord position due to lack of track gauge in curve.

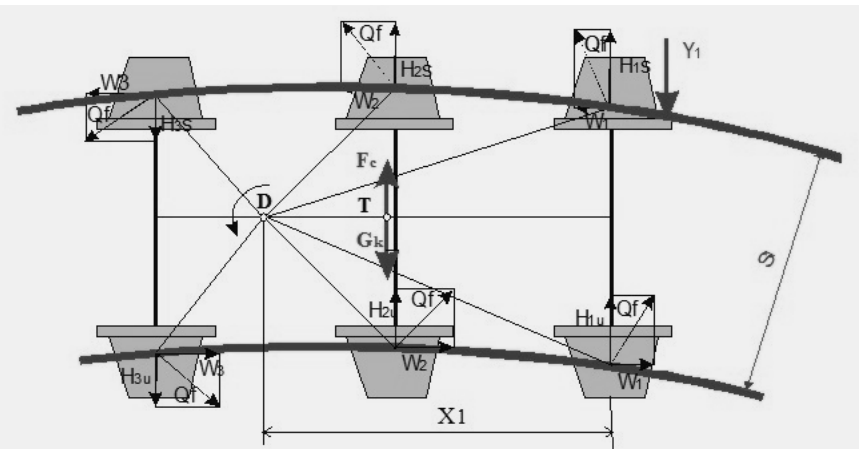

Figure 1. Inclined loose position of three axle bogie in curve (guiding force Y1 that acts on the outer wheel of the first axle, lateral forces Hi and longitudinal friction forces Wi, centrifugal force $\mathrm{Fc}$, weight $G$ ) and current centre of rotation $D$

Fig. 2 shows gauge of wheel set (q), gap (d), track gauge and flange thickness.

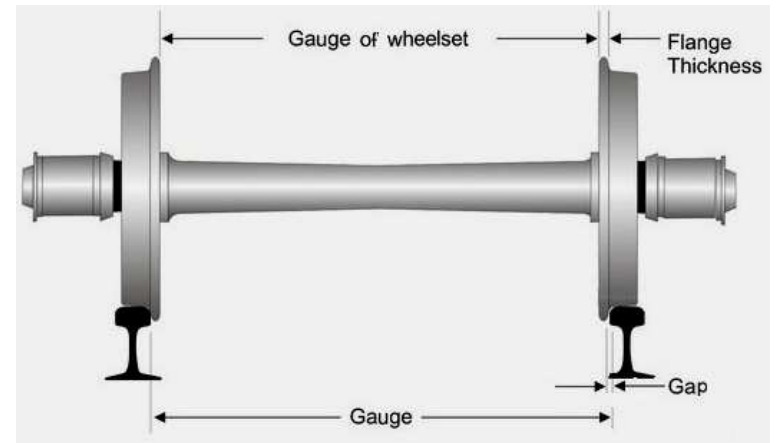

Figure 2. Principal geometric parameters of wheel set and track

Fig. 3 shows initial position of track rails in curve with nominal track gauge according to defined tolerance $1435 \pm 3 \mathrm{~mm}$.

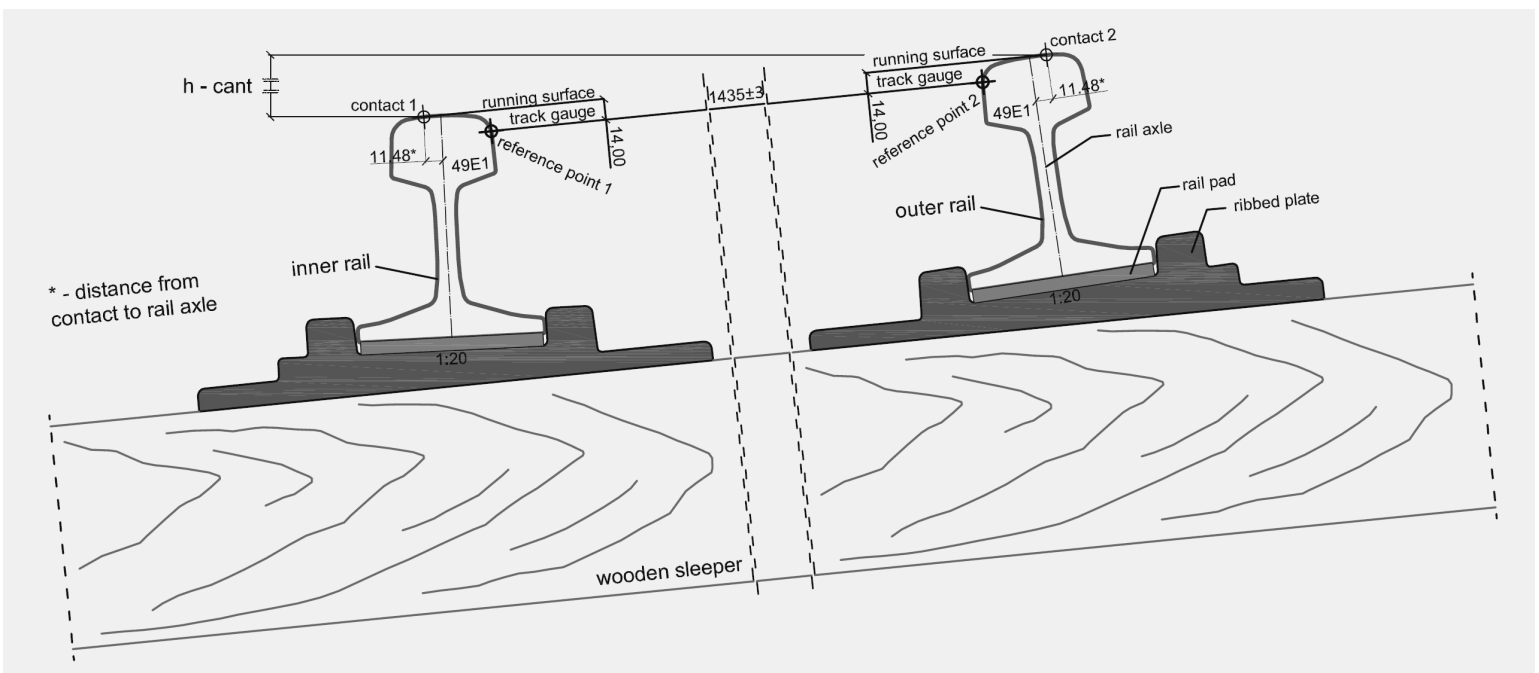

Figure 3. Initial position of track rails in curve without track widening

Fig. 4 shows calculated gap value $\delta \mathrm{s}=\mathrm{f}=12.5 \mathrm{~m}$ between flange of outer wheel on the mid axle, and outer rail in curve with radius $\mathrm{R}=300 \mathrm{~m}$ for chord position according to formula (1). Also, it shows total available gap in track is $\delta=9-25 \mathrm{~mm}$. 


$$
\mathrm{f}=\frac{L^{2}}{4 \cdot 2 \cdot \mathrm{R}}=\frac{5.4^{2}}{8 \cdot 300}=12.15 \mathrm{~m}
$$

According to calculated gap value $f=12.15 \mathrm{~mm}$ in curve with radius $\mathrm{R}=300 \mathrm{~m}$ (Fig. 4), it is obvious that inner wheel doesn't have sufficient track gauge for curve traversing in inclined position, neither in chord position with total available gap $\delta<12.15 \mathrm{~mm}$.

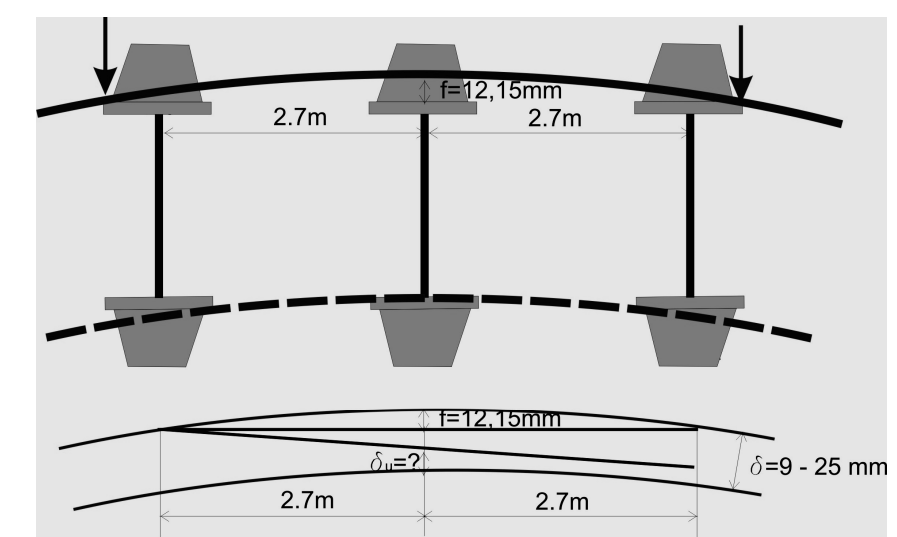

Figure 4. Necessary gaps: (up) $\delta s=f$ between flange of outer wheel on the mid axle and outer rail (down) $\delta$ u between flange of inner wheel on the mid axle and inner rail (locomotive type JŽ 461 , radius $\mathrm{R}=300 \mathrm{~m}$, chord and inclined position)

Fig. 5 presents possible speeds and possible positions of bogie of locomotive type JŽ 461 in inclined loose position during curve traversing (curve radius $\mathrm{R}=300 \mathrm{~m}$, cant $\mathrm{h}=150 \mathrm{~mm}$, without track widening and with gap range $\delta=9-25 \mathrm{~mm}$ ). Grey cells show impossible positions for gap $\delta \mathrm{s}$ (between wheel flange of third axle and outer rail) and gap $\delta u$ (between wheel flange of third axle and inner rail). In these cases, inner wheel of mid axle doesn't have enough gap for traversing the curve without track gauge widening. Necessary gap value between inner wheel of mid axle and gauge face of inner rail was calculated according to Fig. 3, using the equation (2).

$$
\delta_{2 u}=\delta-f-0.5 \cdot \delta_{s}
$$

where:

$\delta_{2 u}$ - gap between inner wheel of mid axle and gauge face of inner rail,

$\delta$ - total gap,

$f$ - gap between flange of outer wheel on the mid axle and outer rail,

$\delta$ s - gap between flange of outer wheel on third axle and outer rail.

In case of inclined position with maximum $\delta \mathrm{s}=25 \mathrm{~mm}$ and $\delta \mathrm{u}=0 \mathrm{~mm}$, traverse speed is slightly higher than designed speed $(\mathrm{V}=80 \mathrm{~km} / \mathrm{h})$ and it amounts $84 \mathrm{~km} / \mathrm{h}$. It means that three axle bogie, without track gauge widening in curves, takes the chord position with traverse speed lower than 84 $\mathrm{km} / \mathrm{h}$.

In case of low curve traverse speed, it occurs cant excess of outer rail and additional load on inner rail. Designed cant for speed $V=80 \mathrm{~km} / \mathrm{h}$ and $\mathrm{R}=300 \mathrm{~m}$ amounts $150 \mathrm{~mm}$. For speed $\mathrm{V}=50 \mathrm{~km} / \mathrm{h}$, it occurs cant excess.

Track gauge widening of $10 \mathrm{~mm}$ in curve with radius $\mathrm{R}=300 \mathrm{~m}$ and cant $\mathrm{h}=150 \mathrm{~mm}$, would allow inclined loose position for vehicle traverse speed equal to designed speed. ( $\mathrm{V}=80 \mathrm{~km} / \mathrm{h}$ ). 


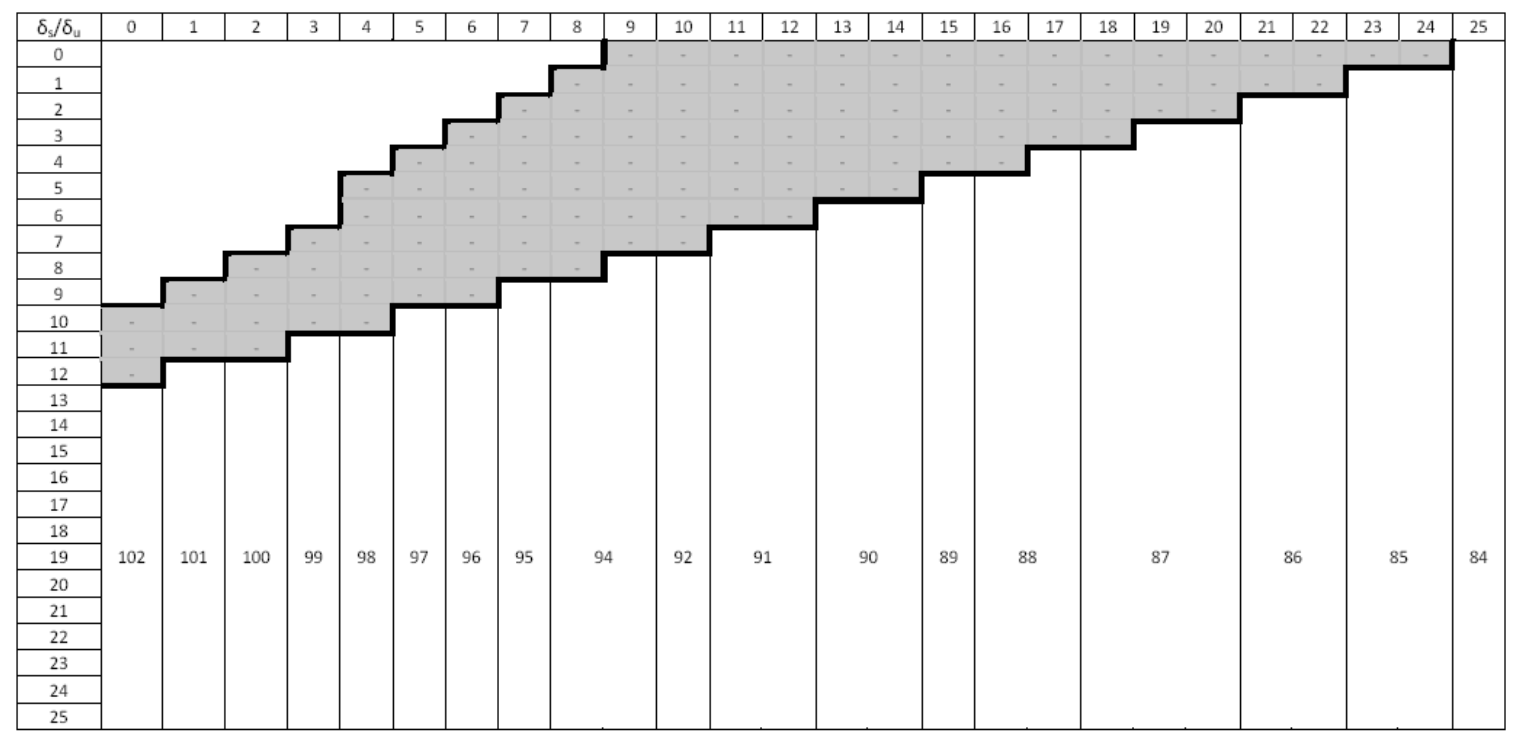

Figure 5. Possible traverse speeds for bogie in inclined position, without track widening, in curve with radius $\mathrm{R}=300 \mathrm{~m}$

Next calculation in Tab. 1 can prove previous consideration and statement. Calculation uses symbols according to Fig. 1 and Software [10].

Calculated uncompensated lateral acceleration is directed towards field region of curve, when the vehicle speed is $80.42 \mathrm{~km} / \mathrm{h}$. Therefore, track gauge widening of $10 \mathrm{~mm}$ in curve with radius $\mathrm{R}=300$ $\mathrm{m}$ and cant of $150 \mathrm{~mm}$, would allow inclined loose position with designed speed of $80.4236 \mathrm{~km} / \mathrm{h} \approx$ $80 \mathrm{~km} / \mathrm{h}$. Furthermore, the calculation in Table 1 was carried out for the analysis of the traverse of three axle bogie of locomotive type JŽ 461 through the curve with radius $\mathrm{R}=500 \mathrm{~m}$ with speed of $80 \mathrm{~km} / \mathrm{h}$. Calculated uncompensated lateral acceleration is directed towards field region of curve, when the vehicle speed is approximately $80 \mathrm{~km} / \mathrm{h}$. Calculation proves that inclined loose position of three axle bogie, that traverse with speed $\mathrm{V}=80 \mathrm{~km} / \mathrm{h}$ through curve with radius $\mathrm{R}=500 \mathrm{~m}$, without track gauge widening, is possible if gap combination is $\delta \mathrm{s}=23.5 \mathrm{~mm}$ and $\delta \mathrm{u} \leq 1.5 \mathrm{~mm}$. Values lower than $\delta \mathrm{s}=23.5 \mathrm{~mm}$ would allow higher traverse speed than $80 \mathrm{~km} / \mathrm{h}$. Values lower than $\delta \mathrm{s}=23.5 \mathrm{~mm}$ implies chord position of three axle bogie of locomotive type $J \check{Z} 461$ in curve with radius $\mathrm{R}=500 \mathrm{~m}$ for speeds $\mathrm{V}<80 \mathrm{~km} / \mathrm{h}$. If $\delta \mathrm{s}=28 \mathrm{~mm}$ and $\delta \mathrm{u} \leq 7 \mathrm{~mm}$, inclined position of three axle bogie in curve with radius $\mathrm{R}=500 \mathrm{~m}$ is possible for speed $\mathrm{V}=49.5295 \mathrm{~km} / \mathrm{h} \approx 50 \mathrm{~km} / \mathrm{h}$. This being the case, necessary track gauge widening ranges from 3 to $10 \mathrm{~mm}$.

Table 1. Curve traversing of three axle bogie through curve with radius $\mathrm{R}=300 \mathrm{~m}$ and $\mathrm{R}=500 \mathrm{~m}$, as well as vehicle speed $\mathrm{V}=80 \mathrm{~km} / \mathrm{h}$

\begin{tabular}{|l|c|c|}
\hline \multicolumn{1}{|c|}{ Input data } & $\mathrm{R}=300 \mathrm{~m}$ & $\mathrm{R}=500 \mathrm{~m}$ \\
\hline Measured track gauge widening $[\mathrm{mm}]$ & 10 & 0 \\
\hline Range of available total gap $\delta[\mathrm{mm}]$ & $19-35$ & $9-25$ \\
\hline $\begin{array}{l}\text { Gap betwen flange of inner wheel on third axle and inner rail } \delta \mathrm{u} \\
{[\mathrm{mm}]}\end{array}$ & 3 & 1.5 \\
\hline Gap betwen flange of outer wheel on third axle and outer rail $\delta \mathrm{s}[\mathrm{mm}]$ & 32 & 23.5 \\
\hline \multicolumn{2}{|c|}{ Output data } & 0.22 \\
\hline Creep coefficient & 91.9856 & 84.551 \\
\hline Guiding force $\mathrm{Y}_{1}$ that acts on the outer wheel of the first axle $[\mathrm{kN}]$ & 21.6938 & 21.744 \\
\hline Guiding force $\mathrm{Y}_{1 \mathrm{u}}=\mathrm{H}_{1}$ on the inner wheel of the first axle $[\mathrm{kN}]$ & 48.598 & 41.062 \\
\hline $\mathrm{Y}_{1 \mathrm{r}}=\mathrm{Y}_{1}-2 \mathrm{H}_{1}$ Force that acts on the first axle $[\mathrm{kN}]$ & 101.747 & 60.67 \\
\hline Centrifugal force $\mathrm{F}_{\mathrm{c}}[\mathrm{kN}]$ & 80.42 & 80.17 \\
\hline Vehicle speed in curve $[\mathrm{km} / \mathrm{h}]$ & 0.689 & 0.403 \\
\hline Uncompensated lateral acceleration $\mathrm{p}_{\mathrm{s}}\left[\mathrm{m} / \mathrm{s}^{2}\right]$ &
\end{tabular}




\section{Track gauge widening analysis}

According to calculation, due to large distance between first and middle i.e. middle and last axle, it occurs increased lateral forces during curve negotiation, as it was shown in calculation (Tab. 1). These lateral forces are not hazardous for derailment, but they have significant influence on the track in small radius curve. Axle load of locomotive is $200 \mathrm{kN} \pm 3 \%$. This load is distributed on both wheels, but this distribution is not equal during curve negotiation. For example, in case of cant excess, load on inner rail in curve might be significantly larger than $100 \mathrm{kN}$.

With increase of operational load (MGT - million gross-tones), it can be expected track gauge widening and deviation of designed geometry.

In addition, gauge-face wear of rails, rigid rail fastening system, plastic deformation of rail pad, the embedment of ribbed plate into upper side of wooden sleeper, convexity of a twinblock concrete or wooden sleeper etc. influence the track gauge widening. This deformation is more significant on rail pads under inner rail due to cant excess, when ordered speed was lower than designed speed, and due to chord position of three axle bogie.

Infrastructure manager makes a decision on the track gauge widening in small radius curve according to the performance of the vehicle and characteristics of the track [11].

Tab. 2 shows the values of the track gauge widening in small radius curve prescribed by The Greek infrastructure manager according to the local specifics [12].

Table 2. Gauge widening in small radius curve prescribed by the Greek infrastructure manager according to the local specifics

\begin{tabular}{|c|c|c|c|}
\hline \multirow{3}{*}{ Radius $\mathrm{R},[\mathrm{m}]$} & \multicolumn{3}{|c|}{ Gauge widening [mm] } \\
\hline & \multirow{2}{*}{ Wooden sleeper } & \multicolumn{2}{|c|}{ Concrete sleeper } \\
\hline & & twinblock & monoblock \\
\hline $\mathrm{R} \geq 600$ & \multirow{2}{*}{0} & 0 & \multirow{2}{*}{0} \\
\hline $600>\mathrm{R} \geq 400$ & & \multirow{3}{*}{5} & \\
\hline $400>\mathrm{R} \geq 350$ & 5 & & \multirow{2}{*}{5} \\
\hline $350>\mathrm{R} \geq 300$ & 10 & & \\
\hline $300>\mathrm{R} \geq 250$ & 15 & & 10 \\
\hline $250>\mathrm{R}$ & 20 & & \\
\hline
\end{tabular}

The immediate action limit values given in standard SRPS EN 13848-5 are derived from European experience and from theoretical considerations of the wheel-rail interaction. Physical tests with different vehicles up to the point of derailment are not practicable. The immediate action limits given in the Tab.3 and are normative.

Table 3. Gauge widening according to [13]

\begin{tabular}{|c|c|c|c|c|}
\hline \multirow{3}{*}{ Speed $[\mathrm{km} / \mathrm{h}]$} & \multicolumn{4}{|c|}{ Track gauge - (IAL) Immediate action limit } \\
\hline & \multicolumn{2}{|c|}{$\begin{array}{c}\text { Isolated defects - Nominal track } \\
\text { gauge to peak value Isolated } \\
\text { defects - Nominal track gauge to } \\
\text { peak value [ } \mathrm{mm}]\end{array}$} & \multicolumn{2}{|c|}{$\begin{array}{c}\text { Nominal track gauge to mean track } \\
\text { gauge over } 100[\mathrm{~mm}]\end{array}$} \\
\hline & Minimum & Maximum & Minimum & Maximum \\
\hline $\mathrm{V} \leq 40$ & \multirow{2}{*}{-11} & \multirow{2}{*}{+35} & Not applic. & +32 \\
\hline $40<\mathrm{V} \leq 80$ & & & -8 & +32 \\
\hline $80<\mathrm{V} \leq 120$ & -11 & +35 & -7 & +27 \\
\hline $120<\mathrm{V} \leq 160$ & -10 & +35 & -5 & +20 \\
\hline $160<\mathrm{V} \leq 230$ & -7 & +28 & -5 & +20 \\
\hline $230<\mathrm{V} \leq 300$ & -5 & +28 & -3 & +20 \\
\hline
\end{tabular}


Derailments caused by gauge widening usually involve a combination of wide gauges and large lateral rail deflections (rail roll), as shown in Figure 6 . A maximum $31.5 \mathrm{~mm}$ gauge widening (include the rail gauge wear measured under an unloaded condition) from the standard value is allowed for a freight vehicle operating in the speed range from 40 to $60 \mathrm{~km} / \mathrm{h}$, if a maximum permissible wear of wheel flange is $15 \mathrm{~mm}$ [14].

It is obvious that values in Tab. 3 match with values from considerations by Iwnicki [14].

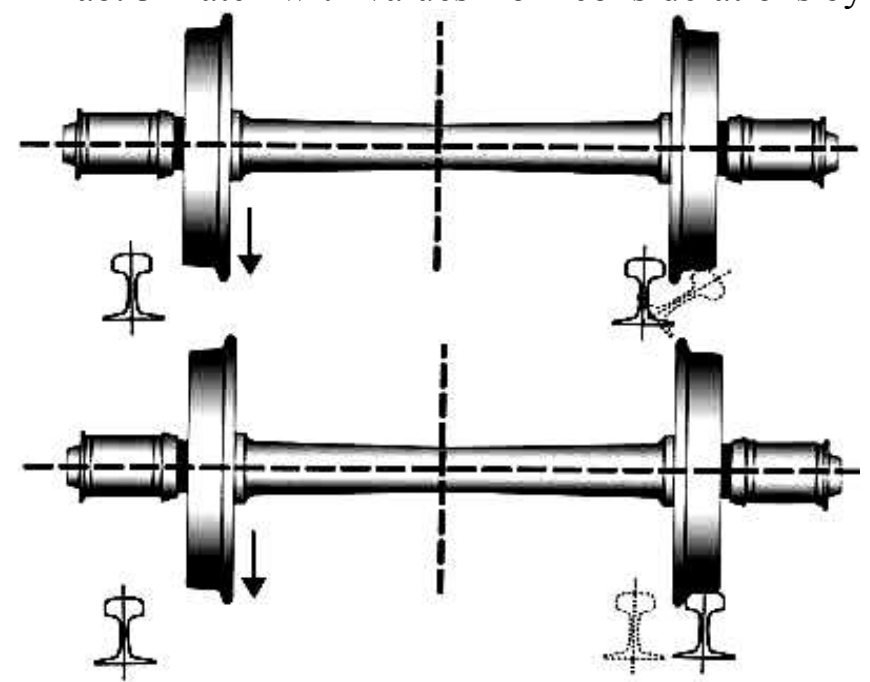

Figure 6. Possible derailment due to gauge widening [14]

\section{Summary}

Analysis of cause and mechanism of track gauge widening phenomenon in curve radii from $300 \mathrm{~m}$ to $500 \mathrm{~m}$, indicates that track gauge widening is influenced by bogie construction, reduced speeds in relation to the designed speed and cant excess, as well as rigid fastening system and type of sleeper. Gauge widening shall be provided at circular curve sections to prevent excessive lateral force on the track, taking the curve radius and bogie wheelbase of rolling stock into consideration. This rule does not apply, however, to those cases where the radius of curve is large, the wheelbase of rolling stock is short and/or there is no chance for the excessive lateral force to be generated. Gauge widening shall be gradually increased over the adequate distance in order not to impair safe car operations, taking the bogie wheelbase of rolling stock into consideration.

\section{ACKNOWLEDGEMENT}

This work was supported by the Ministry of Education, Science and Technological Development of the Republic of Serbia through the research project No. 36012: "Research of technicaltechnological, staff and organisational capacity of Serbian Railways, from the viewpoint of current and future European Union requirements" and joint Slovak - Serbian project No. 680-00-140/201209/10: "Reconstruction and revitalization of railway infrastructure in accordance with regional development".

\section{References}

[1] Roanes-Lozano, E., Galán-García, J. L., García-Álvarez, A., Mesa, L. Estimating radial railway network improvement with a CAS (2014) Journal of Computational and Applied Mathematics, Vol. 270, pp. 294-307

[2] Duffy, M.C. George Stephenson and the introduction of rolled railway rail (1981) Journal of Mechanical Working Technology, Vol. 5, (3-4), pp. 309-342.

[3] Roanes-Lozano, E., Laita, L. M., Roanes-Macías, E., Wester, M. J., Ruiz-Lozano, J. L., Roncero. C. Evolution of railway network flexibility: The Spanish broad gauge case (2009) Mathematics and Computers in Simulation, Vol. 79, (8), pp. 2317-2332. 
[4] Zhang, J., Xu, B., Guan, X. A combined simulation procedure for wear assessment of the HXN5 locomotive (2014) Vol. 314(1-2) 15 pp. 305-313.

[5] Ma, W., Song, R., Liu, W., Luo, S. The influence of journal box position error on wheelset asymmetric flange wear of the 2C0-type locomotive (2014) Vol. 314(1-2), pp. 314-320.

[6] Vo, K.D., Zhu, H.T., Tieu, A.K., Kosasih, P.B. FE method to predict damage formation on curved track for various worn status of wheel/rail profiles (2014) Wear, Vol. 324, pp. 654-662.

[7] Descartes, S., Saulot, A., Godeau, C., Bondeux, S., Dayot, C., Berthier, Y. Wheel flange/rail gauge corner contact lubrication: Tribological investigations (2011) Wear, Vol. 271, (1-2), pp.5461

[8] Kovačič, B., Kamnik, R., Premrov, M. Deformation measurement of a structure with calculation of intermediate load phases (2011) Survey Review, 43 (320), pp. 150-161.

[9] Ćosić, M., Brčić, S. Iterative Displacement Coefficient Method: Mathematical formulation and numerical analyses (2013) Gradjevinar, 65 (3), pp. 199-211.

[10] Popović, Z. Program za proračun prolaska obrtnog postolja kroz krivinu [Program for budget passage bogie in curves] (1999) Građevinski fakultet u Beogradu, 273 p.

[11] Popović, Z., Lazarević, L. Defining the cause and mechanism of track widening phenomenon on reconstructed sections Trebaljevo - Kolašin and Mijatovo Kolo - Mojkovac on rail line Vrbnica Bar, The Case Study (2013) Montenegro, 185 p.

[12] Provisional national technical specifications, 07-03-01-10 (2006) 48, 274 p.

[13] CEN: EN 13848 - Railway applications - Track - Track geometry quality - Part 5: Geometric quality levels - Plain line, (2010)

[14] Iwnicki, S. Handbook of Railway Vehicle Dynamics (2006) Taylor \& Francis Group, 262 p. 
Innovative Technologies in Development of Construction Industry

10.4028/www.scientific.net/AMM.725-726

Analysis of Track Gauge Widening in Curves with Small Radius

10.4028/www.scientific.net/AMM.725-726.967 